\title{
Drivers and Attitudes towards Online Shopping: Comparison of Turkey with Romania
}

\author{
Durmuş Yörük ${ }^{1}$, Süleyman Dündar ${ }^{2}$, \\ Liliana Mihaela Moga $^{3}$ and Mihaela Neculita ${ }^{3}$ \\ ${ }^{1}$ Department of Business Administration, Afyon Kocatepe University, Turkey \\ ${ }^{2}$ Statistics Department, Afyon Kocatepe University, Turkey \\ ${ }^{3}$ Faculty of Economics and Business Administration, Dunarea de Jos University of Galati, Romania
}

\begin{abstract}
The purpose of this study is to examine the shopping and buying behavior of consumers and their attitudes toward internet shopping in both Romania and Turkey. Another purpose is also finding out critical factors or drivers of online businesses to be successful and being able to compete in global environment. 185 students from Afyon Kocatepe University in Turkey and 142 students from Dunarea de Jos University of Galati in Romania completed the survey regarding their online shopping and buying experiences and attitudes towards online shopping. We also used unstructured interviews with these student groups to learn more about attitudes of consumers toward online shopping. The data shows that customers are still hesitating to shop online in both countries. The most important reasons for consumers in both countries not to shop online are online security, preference to shop traditional way, prefer to buy by touching and feeling and willing to use products immediately. The results of the study also show that although consumers either buy or plan to buy books, tickets, CDs, software online, they don't want to buy groceries online in either country. The most important reasons to shop online both in Romania and Turkey are being able to get detailed product information, home delivery, convenience, product quality and lower prices. Overall results regarding the attitudes of consumers toward online shopping are positive. So, they either would like to buy online or continue to buy. They also think that online shopping has advantages for buying books, CDs, tickets. These results also have some practical implications for managers and strategists of online stores.
\end{abstract}

Keywords: e-commerce, online shopping, attitudes, consumer behavior

\section{Introduction}

Popularization of internet and e-commerce has been one of the most important social and business developments of the last decade. Online shopping has become the third most popular internet activity following the e-mail usage and web browsing. Everything that consumers want and need to buy presents a potential for online business.

Internet is changing the way how consumers shop and buy goods and services. Many companies have started using the internet with the aim of cutting marketing costs, thus, reducing price of their products and services in order to stay

Copyright (C) 2011 Durmuş Yörük, Süleyman Dündar, Liliana Mihaela Moga and Mihaela Neculita. This is an open access article distributed under the Creative Commons Attribution License unported 3.0, which permits unrestricted use, distribution, and reproduction in any medium, provided that original work is properly cited. Contact author: Liliana Mihaela Moga E-mail: liliana.moga@gmail.com 
ahead in highly competitive markets. Companies also use the internet to convey, communicate and disseminate information, to sell product, to take feedback and also to compare prices, product features and after sale service facilities they will receive if they purchase the product from a particular store (Shergill and Chen, 2005: 79-80).

There have been many entrepreneurs taking advantage of this opportunity and established e stores. Dell, Amazon, Office Max are some examples in the world. Kangurum.com, Hepsiburada.com, Weblebi.com, Migros.com and Gima.com are examples from Turkey. According to the latest annual results provided by the Minister of Finances regarding the companies dealing with e-commerce, www.emag.ro holds the top position followed by www.pcfun.ro, www.pcgarage.ro, www.marketonline.ro and www.cel.ro in Romania (www.mfinante.ro). The Romanian ecommerce market has been constantly expanding and this aspect can be noticed by taking into account both the increasing number of online shops and the number of visitors that is gradually increasing, visitors that change into buyers of goods on the internet

(http://www.sellerator.ro/stiri.html).

Due to the busy schedule, heavy traffic and easy access to the internet and also the wide range of services and products that are available on the internet, Romanians turned their attention to online shops. Competitive prices, home delivery services after working hours and weekends contributes significantly to the development of this new branch of commerce electronic commerce. (http://www.sellerator.ro/stiri.html).

One of the biggest challenges of e-stores is attracting enough online customers to be profitable and survive. Volume is the key to success for online stores. If they are not able to attract and retain enough customers, they are not going to be able to survive. That is why changing the shopping behaviors and attitudes of consumers toward e-shopping are key to success for online stores.
Online shopping behavior refers to the process of purchasing products and services via the internet. The process consists of five steps similar to those associated with traditional shopping behavior. In the typical online shopping process, when potential consumers recognize a need for some merchandise or service, they go to the internet and search for need- related information. They then evaluate alternatives and choose the one that best fits their criteria for meeting that felt need. Finally, a transaction is conducted and post-sale services provided. Online shopping attitudes refer to consumers' psychological state in terms of making purchase in the internet ( $\mathrm{Li}$ and Zang, 2002: 508).

There have been many studies examined the relationship between factors affecting consumer' online buying behavior and the relationship between these factors. One of the main goals of these studies are helping practitioners or managers of e-stores to choose and implement right competitive and marketing strategies to convert potential customers into active ones, while retaining existing online customers, as well.

The main focus of this study is to find out why consumers are reluctant to shop online, what kind of products they are willing to buy online and whether their attitudes towards online shopping is positive or negative. Why current ecustomers use online shopping? What kind of products do they buy or did they buy? Will they continue to shop online? What should entrepreneurs and managers of estores do to attract new customers and retain the current ones? What kind of competitive, marketing and operational strategies should they implement? Are there any differences between attitudes of Romanian and Turkish consumers towards online shopping?

\section{Literature Review on Online Shopping}

There have been many studies focused on identifying the factors which affect the willingness of consumers to buy online or to engage in internet shopping. Researchers focused on different aspects of e-commerce and shopping behaviors of 
consumers. They first focused on internet usage and factors affecting it. Noce and McKeown used data from the Canadian Internet Use Survey (CIUS) to explore the extent of demographic variables affect internet usage by individuals in Canada. A logistic model confirms that certain factors, educational attainment, and geography in particular influence internet usage in Canada, controlling for age and income. Education maintains a strong, significant impact on internet usage such that the odds of using the Internet are about three times greater for someone who has some postsecondary education than someone who has, at most, a high school education (Noce and McKeown, 2008:462).

Bosnjak, Galesic, and Tuten study uses data from an online consumer panel (808 online shoppers) to develop a hierarchical model of personality which is useful for predicting consumer intentions to purchase products and services online. They tried to answer the question of "What determines one's willingness to purchase products online?" Their research results mention that there are five factors affecting the likelihood of future online purchases. These are Neuroticism, Openness to Experiences, Agreeableness, Need for Cognition, and Online Shopping Experience. Three of them are Neuroticism, Openness to Experiences, Agreeableness, - have small, but significant influences on the willingness to buy online. In addition, Need for Cognition has a direct negative effect. Lack of online shopping experience could underline the effects of personality traits on the estimation of likelihood of future online purchases. They also imply that the decision to shop online is made with emotion rather than reasoning. (Bosnjak, Galesic, and Tuten, 2007).

Soopramanien and Robertson (2007) studied and modeled how sociodemographic variables, attitudes and beliefs towards internet shopping affect both the adoption decision and usage of the online shopping channel. They determined different behaviors of three groups of consumers. First group is consumers that buy online, second is consumers just browse online but purchases in-store and the last one is consumers that do not shop online at all. They found out that online shoppers find buying online is more convenient than browsers and non internet shoppers. They also mentioned that brand name of products do not influence the behavior of either consumer groups.

Vijayasarathy (2004:747-762) tried to predict consumer intentions to use online shopping by applying Technology Acceptance Model. Technology Acceptance Model looks at the usefulness and ease of use variables only. Vijayasarathy also included compatibility, privacy, security, normative beliefs, and self- efficacy to the Technology Acceptance Model. He used data collected from 281 consumers. His results show that except privacy, all other variables are predictors of attitudes of consumers towards online shopping.

McCloskey and Whiteley (2002: 185-195) conducted a study on both in the US and UK and compared the results. They noted that both US and UK consumers have positive attitudes toward online shopping. Both groups agreed on that e-commerce is convenient and advantageous for the purchase of CDs, books and travel tickets. Both groups also mentioned that online security was a big problem. They mentioned that e-commerce is not advantageous for purchasing groceries online. Those individuals who purchased online were more positive about online commerce than individuals who have not used internet. Case and Dick (2001: 900907) used an online survey on 425 US undergraduate and graduate students in 2001 and found out that internet knowledge, income and education level are especially important predictors of online purchases among university students.

Jarvenpaa, Tractinsky and Vitale (2000: 4571) investigated how consumer's perceived store size and reputation influence their trust in the store, risk perception, attitudes and willingness to buy at the specific store. They discovered that there is a positive relationship between consumer trust in internet stores and the store's perceived reputation and size. Higher consumer trust reduces perceived risks associated with internet shopping and generates more favorable attitudes towards shopping at a particular store. Bellman, Lohse and Johnson (1999: 32-38) examined the 
relationship among demographics, personal characteristics, and attitudes towards online shopping. They found that people who use internet more, and who are more time starved and constrained tend to buy online more frequently and as a result they have positive attitudes toward eshopping.

Shergill and Chen (2005: 79-94) examined consumer attitudes towards online shopping in New Zealand. They look at the factors which online New Zealand buyers keep in mind while shopping online. They found that website design, website reliability/fulfillment, customer service and website security/privacy are the four dominant factors which influence consumer perceptions of online purchasing. Sorce, Perotti and Widrick (2005: 27-37) examined the shopping and buying behavior of younger and older online shoppers in terms of their attitudes toward internet shopping. They used data collected from 300 students and staff in one of the US University. Their results show that while older online shoppers search for significantly fewer products than their younger counterparts, they actually purchase as much as younger consumers. Younger consumers were more likely to agree that online shopping was more convenient than older consumers do.

Shih (2003: 351-368) developed a model to predict consumer acceptance of e-shopping based on the theory of reasoned action and the technology acceptance model. They used data collected from 212 questionnaires which analyzed by using multiple regression. Their results show that individual attitudes toward e-shopping are strongly and positively correlated with user acceptance. Perceived ease of use and perceived usefulness significantly determine individual attitudes toward eshopping. Liao and Cheung (2001: 299306) analyzed consumer attitudes towards internet shopping by using data from consumers in Singapore. They used regression analysis in their study and found out that life content of products, security, price, vendor quality; IT education and internet usage affect the initial willingness of Singaporeans to shop on the internet.
Lian and Lin (2007:48-65) explored effects of different types of products on online buying behavior of consumers. They demonstrated that online shopping acceptance differ among product and service types. Additionally, they mentioned that influence of web security, privacy concerns and product involvement on consumer acceptance of online shopping differ according to product types.

Market research on e-commerce conducted by Gemius in partnership with Orange found out that more than two thirds of the Romanian internet users display a positive attitude concerning the shopping activity (in general) whereas only $6 \%$ of them declare they don't like shopping or even hate shopping. The general positive attitude of the Romanian internet users regarding this particular activity has a positive influence on the increasing number of online buyers.

Although the online commerce popularity has been spreading, the Romanian internet users believe that online shopping is rather risky. We should expect their fears to decrease concerning the online transactions as the internet users take better advantage of the online commerce. Nevertheless online transactions have been regarded as risky by almost half of the internet users increasing by $4 \%$ compared with the percentage recorded in 2006 . Moreover the risk of online shopping seems to be the main concern of the respondents when they are asked about their opinion regarding the online commerce

(http://www.underclick.ro/articol-2613cumparaturile_online_in_romania.html)

Finally, Barutçu (2007:232-241) also analyzed e-customer satisfaction level from cargo carriers. He used the data gathered from e-customers with 178 questionnaires returned. He found out that e-customers are strongly satisfied with the service quality of cargo carriers but are strongly dissatisfied from paying shipping costs. Ecustomers repurchase decisions are affected from cargo carriers' service quality and shipping cost. Li and Zhang (2002: 508-513) looked at 35 empirical studies related to consumer online shopping 
attitudes and identified total of ten interrelated factors for which the empirical evidences show significant relationships. These ten factors are external environment, demographics, personal characteristics, vendor/service/product characteristics, attitude towards online shopping, intention to shop online, online shopping decision making, online purchasing, website quality and consumer satisfaction. They found that three of the five dependent variables which are consumer attitudes, intentions and purchasing behavior and three independent variables which are personal characteristics, vendor/service/product characteristics and website quality received the most attention. They also found that personal characteristics, vendor/service/product characteristics, and website quality significantly affect online shopping attitudes, intentions, and behavior.

Review of the above studies indicated that there hasn't been a systematic research done in e-commerce area and especially attitudes of consumers towards internet or e-shopping comparing two different developing countries and cultures recently. In addition, other studies are focused on between either developed countries or European member countries. We have chosen Turkey as non-member of EU and Romania as a member country to be able to see the differences on attitudes of consumers on member and non member EU countries. When we looked at the other EU and non-EU member countries, in terms of GDP Per Capita, Literacy Rate, Human Development Index, Corruption Perception Index, Inflation and Unemployment rates Turkey and Romania are similar (http://www.aneki.com/comparison.php?c ountry_1=Turkey\&country_2=Romania).

In addition Turkey and Romania clustered in same category on most of the studies comparing Turkey with EU countries (Turanll and Others, 2006; Sandal and Others, 2005). These were the two most important reasons why we decided to choose Turkey and Romania rather than other countries. Our objective in this research is to begin the study that focuses in this area to fill this gap. We will start by implementing a basic study by investigating the attitudes of students toward e-shopping both in Romania and Turkey. We will also try to find out what factors affect the attitudes of consumers to shop online and compare the findings with previous research results.

\section{Methodology}

\section{Population Sample}

The sample consisted of graduate students at Afyon Kocatepe University in Turkey and Dunarea de Jos University in Romania. The questionnaires were distributed to graduate students who are selected randomly. Students were asked to fill out the survey and return it to us immediately. 227 surveys distributed and 185 responses have been received in Afyon Kocatepe University. 187 surveys distributed and 142 of them returned in University of Galati. Total of 327 surveys have been used in the analysis.

\section{Measures:}

Respondents were asked demographic questions including gender, age, education, major, their internet usage at work and home, whether they shop online or not. If they have never shopped online, they were asked what the reasons were for this. If they shopped online, what kind of products did they buy? In addition to these questions, respondents were asked to rate eleven statements concerning the reasons to shop online and 14 questions regarding their attitudes toward internet on a fivepoint scale from 1=strongly disagree to $5=$ strongly agree.

\section{Data Analysis and Results}

\section{Sample Profile}

Demographic features of the respondents are exhibited in Table 1 below. $83.8 \%$ of the respondents are female while $16.2 \%$ of them are male in Romania and $42.7 \%$ of the respondents are female and $57.3 \%$ of them are male in Turkey. Since our sample consists of graduate level students, $93 \%$ of respondents in Romania and $88.6 \%$ in Turkey are at the age of between 20 and $24.83 \%$ of the respondents are Master and $17 \%$ are PhD students in Romania and $80 \%$ 
of respondents are master and 20\% are PhD students in Turkey. All of the respondents are majoring in business administration in both universities.

Table 1: Demographic Information

\begin{tabular}{|c|c|c|c|c|c|}
\hline & & Romania & Turkey & Romania & Turkey \\
\hline & & Frequency & Frequency & $\%$ & $\%$ \\
\hline \multirow{2}{*}{ Gender } & Female & 119 & 79 & 83,8 & 42,7 \\
\hline & Male & 23 & 106 & 16,2 & 57,3 \\
\hline \multirow{4}{*}{ Age } & 20 and younger & 7 & 0 & 4,9 & 0,0 \\
\hline & $20-24$ & 132 & 164 & 93,0 & 88,6 \\
\hline & $25-29$ & 2 & 13 & 1,4 & 7,0 \\
\hline & $30-34$ & 1 & 8 & 0,7 & 4,3 \\
\hline \multirow{2}{*}{ Education } & Masters & 118 & 148 & 83,1 & 80,0 \\
\hline & $\mathrm{PhD}$. & 24 & 37 & 16,9 & 20,0 \\
\hline
\end{tabular}

\section{Internet Access for Consumers}

As indicated in Table 2, 62\% of the respondents in Romania and all of the respondents in Turkey have internet access at school. All of the respondents in Romania and only $35.7 \%$ of the respondents in Turkey have internet access from their homes or dormitories. In addition, the majority of the respondents are using internet between 3-6 years in Romania (64\%) and 2-4 years in Turkey (72.5\%).

While internet access and usage is very high in both countries, about $35 \%$ of the respondents in Romania and $25 \%$ of the respondents in Turkey did not purchase products online. $65 \%$ of respondents in Romania and $75 \%$ of the respondents in Turkey purchased products online. Out of this $65 \%$ in Romania, about $27.5 \%$ shopped online $1-2$ times, $21.8 \%$ of them $3-4$ times, $7.7 \%$ of them 5-6 times and only $7.7 \%$ shopped more than 7 times. Out of this $75 \%$ in Turkey, about $24.9 \%$ shopped online $1-2$ times, $23.8 \%$ of them $3-4$ times, $15.7 \%$ of them 5-6 times and only $10.3 \%$ shopped more than 7 times. It basically shows that consumers in Turkey are reluctant to shop online even if they spend long hours on internet. 
Table 2: Internet Access

\begin{tabular}{|c|c|c|c|c|c|}
\hline & & Romania & Turkey & Romania & Turkey \\
\hline & & Frequency & Frequency & $\begin{array}{c}\text { Percent } \\
\%\end{array}$ & $\begin{array}{c}\text { Percent } \\
\%\end{array}$ \\
\hline \multirow{2}{*}{ Can you use internet at school? } & Yes & 88 & 185 & 62,0 & 100,0 \\
\hline & No & 54 & 0 & 38,0 & 0,0 \\
\hline \multirow{2}{*}{ Can you use internet at home? } & Yes & 142 & 66 & 100,0 & 35,7 \\
\hline & No & 0 & 119 & 0,0 & 64,3 \\
\hline \multirow{5}{*}{$\begin{array}{l}\text { How long have you been using } \\
\text { internet? }\end{array}$} & 2 and less & 5 & 61 & 3,5 & 33,0 \\
\hline & $3-4$ & 44 & 73 & 31,0 & 39,5 \\
\hline & $5-6$ & 47 & 25 & 33,1 & 13,5 \\
\hline & $7-8$ & 31 & 25 & 21,8 & 13,5 \\
\hline & 8 and more & 15 & 1 & 10,6 & 0,5 \\
\hline \multirow{5}{*}{$\begin{array}{l}\text { How many times a week do you } \\
\text { browse on internet? }\end{array}$} & Never & 3 & 8 & 2,1 & 4,3 \\
\hline & 1-2 kez & 10 & 39 & 7,0 & 21,1 \\
\hline & 3-4 kez & 13 & 23 & 9,2 & 12,4 \\
\hline & 5-6 kez & 21 & 16 & 14,8 & 8,6 \\
\hline & 7 and more & 95 & 99 & 66,9 & 53,5 \\
\hline \multirow{5}{*}{$\begin{array}{l}\text { How many hours do you browse } \\
\text { on internet in a day? }\end{array}$} & Never & 47 & 14 & 33,1 & 7,6 \\
\hline & 1-2 hours & 62 & 68 & 43,7 & 36,8 \\
\hline & 3-4 hours & 18 & 47 & 12,7 & 25,4 \\
\hline & 5-6 hours & 7 & 24 & 4,9 & 13,0 \\
\hline & 7 and more & 8 & 32 & 5,6 & 17,3 \\
\hline \multirow{5}{*}{$\begin{array}{l}\text { How many times did you shop } \\
\text { online? }\end{array}$} & Never & 50 & 47 & 35,2 & 25,4 \\
\hline & $1-2$ & 39 & 46 & 27,5 & 24,9 \\
\hline & $3-4$ & 31 & 44 & 21,8 & 23,8 \\
\hline & $5-6$ & 11 & 29 & 7,7 & 15,7 \\
\hline & 7 and more & 11 & 19 & 7,7 & 10,3 \\
\hline
\end{tabular}

\section{Reasons for Not Shopping Online}

When we asked the question of what were the reasons for not to shop online, it has seen that the majority of the respondents in Romania prefer traditional shopping (77.5\%), would like to see and feel the products while shopping (54.9\%) and wants to use the products immediately (58.5\%. Respondents in Turkey mainly concern about online security and they prefer traditional way of shopping (about (37\%). These are the responses of people who never shopped online. While when we did interviews with them and asked about the most important reason for not to shop online, they mentioned online security as a main reason especially because they are afraid of sharing personal and credit card information with online stores. 
Table 3: Reasons for Not Shopping Online

\begin{tabular}{|l|r|r|r|r|}
\hline & Romania & \multicolumn{1}{c|}{ Turkey } & Romania & \multicolumn{1}{c|}{ Turkey } \\
\cline { 2 - 5 } & $\begin{array}{c}\text { Frequenc } \\
\text { y }\end{array}$ & $\begin{array}{c}\text { Frequenc } \\
\text { y }\end{array}$ & $\begin{array}{c}\text { Percent } \\
\text { \% }\end{array}$ & $\begin{array}{c}\text { Percent } \\
\text { \% }\end{array}$ \\
\hline Online Security & 49 & 70 & 34,5 & 37,8 \\
\hline Would like to See and feel while buying & 78 & 45 & 54,9 & 24,3 \\
\hline Prefer traditional way of shopping & 110 & 69 & 77,5 & 37,3 \\
\hline $\begin{array}{l}\text { Needs and wants to use products } \\
\text { immediately }\end{array}$ & 83 & 25 & 58,5 & 13,5 \\
\hline Doesn't have a credit card & 27 & 13 & 19,0 & 7,0 \\
\hline
\end{tabular}

\section{Types of E-Commerce Activities}

As indicated in Table 4, consumers mostly purchased books, tickets, CDs, software and hardware products online. They don't want to or did not buy toys, flowers and groceries online. All of the respondents in Romania said that they used internet to buy books while only $58.9 \%$ of the respondents in Turkey said that they buy books online. While 24.3 percent of the respondents in Turkey purchased software online, only $7.7 \%$ of the respondents in Romania purchased software online. In addition, people in Romania use internet to purchase clothing (33.1\%) more than people in Turkey (13\%).

Table 4: Types of Products (What did you buy? or What Would you buy?)

\begin{tabular}{|l|r|r|r|r|}
\hline & \multicolumn{1}{|c|}{ Romania } & Turkey & Romania & Turkey \\
\cline { 2 - 5 } & Frequency & Frequency & $\begin{array}{c}\text { Percent } \\
\text { \% }\end{array}$ & $\begin{array}{c}\text { Percent } \\
\text { \% }\end{array}$ \\
\hline Books & 142 & 109 & 100,0 & 58,9 \\
\hline Hardware & 32 & 71 & 22,5 & 38,4 \\
\hline CDs & 13 & 61 & 9,2 & 33,0 \\
\hline Software & 11 & 45 & 7,7 & 24,3 \\
\hline Tickets & 38 & 62 & 26,8 & 33,5 \\
\hline Travel Ticket & 48 & 48 & 33,8 & 25,9 \\
\hline Clothing & 47 & 24 & 33,1 & 13,0 \\
\hline Toys & 14 & 17 & 9,9 & 9,2 \\
\hline Flowers & 3 & 11 & 2,1 & 5,9 \\
\hline Groceries & 3 & 3 & 2,1 & 3,8 \\
\hline
\end{tabular}

\section{Factors for Online Shopping}

Consumers who shopped online rated convenience (3.96 in Romania and 3.87 in Turkey), prices of products (3.44 and 3.72), detailed information about products $(3.54$ and 3.84), and home delivery ( 4.22 and 3.77) higher than other reasons for online shopping as is shown in Table 5. We realized that Romanian consumers also prefer shopping online because of time constraints (3.79) more compared to Turkish consumers (2.77). Internet security or online security is a biggest hesitation for all e-commerce consumers in both countries. 
Table 5: Factors for Online Shopping

\begin{tabular}{|l|r|r|r|r|r|r|}
\hline & \multicolumn{2}{|c|}{ Romania (n=142) } & \multicolumn{2}{c|}{ Turkey (n=185) } & \multirow{2}{*}{ t } & \multirow{2}{*}{ P } \\
\cline { 2 - 5 } & Mean & Std. Dev. & Mean & \multicolumn{1}{c|}{ Std. Dev. } & & \\
\hline Convenience & 3,96 & 1,35 & 3,87 & 1,01 & 0,67 & 0,503 \\
\hline Prices Of Products & 3,44 & 1,26 & 3,72 & 1,01 & 2,29 & $0,023^{* *}$ \\
\hline More Information & 3,54 & 1,27 & 3,84 & 1,05 & 2,30 & $0,022^{* *}$ \\
\hline Home Delivery & 4,22 & 1,11 & 3,77 & 1,02 & 3,77 & $0,000^{* *}$ \\
\hline Product Quality & 3,06 & 1,19 & 3,75 & 0,97 & 5,77 & $0,000^{* *}$ \\
\hline Service Quality & 3,09 & 1,14 & 3,50 & 1,16 & 3,16 & $0,002^{* *}$ \\
\hline Monthly payments to Credit Cards & 3,08 & 1,36 & 3,26 & 1,23 & 1,31 & 0,187 \\
\hline Trust to E-commerce site & 2,51 & 1,18 & 3,49 & 1,23 & 7,19 & $0,000^{* *}$ \\
\hline Internet Security & 2,64 & 1,29 & 3,15 & 1,41 & 3,37 & $0,001^{* *}$ \\
\hline Time Constraints & 3,79 & 1,27 & 2,77 & 1,34 & 6,99 & $0,000^{* *}$ \\
\hline Weather & 2,89 & 1,39 & 2,43 & 1,56 & 3,28 & $0,001^{* *}$ \\
\hline
\end{tabular}

${ }^{* *}$ significant at $5 \%$ level of significance

\section{Attitudes toward Online Shopping}

We analyzed consumer attitudes toward online shopping both in Romania and Turkey. As it is indicated on Table.6, attitudes of consumers towards online shopping in Turkey is higher (3.30) than the attitudes of consumers toward online shopping in Romania(3.05). E-commerce users in Turkey are more positive concerning internet shopping for CDs, books, tickets, banking services and the convenience of home delivery than ecommerce users in Romania. Both groups reported their concerns about the security of credit card information on the internet. Although both users prefer online shopping and would like to shop online, e-commerce users in Turkey have more positive attitudes (4.05) than e-commerce users in Romania (3.04).

Table 6: Consumer Attitudes toward Online Shopping

\begin{tabular}{|c|c|c|c|c|c|c|c|}
\hline & & \multicolumn{2}{|c|}{ Romania $(n=142)$} & \multicolumn{2}{|c|}{ Turkey $(n=185)$} & \multirow{2}{*}{$\mathbf{t}$} & \multirow{2}{*}{$\mathbf{p}$} \\
\hline & & Mean & Std. Dev. & Mean & Std. Dev. & & \\
\hline & All Factors (Attitude) & 3,05 & 0,80 & 3.30 & 0.62 & 3.17 & $\begin{array}{l}\text { 0.002* } \\
*\end{array}$ \\
\hline \multirow{14}{*}{$\begin{array}{l}\text { Individual } \\
\text { factors of } \\
\text { attitudes } \\
\text { towards } \\
\text { online } \\
\text { shopping }\end{array}$} & Online shopping is more easy & 3,65 & 1,34 & 3,18 & 1,28 & 3,19 & $0,002^{* *}$ \\
\hline & Online shopping is cheaper & 3,06 & 1,25 & 2,90 & 1,15 & 1,25 & 0,211 \\
\hline & Advantages for books & 3,05 & 1,22 & 3,65 & 1,13 & 4,58 & $0,000^{* *}$ \\
\hline & Advantages for CDs & 2,77 & 1,17 & 3,74 & 1,00 & 8,12 & $0,000^{* *}$ \\
\hline & Advantages for Clothing & 3,05 & 1,27 & 2,43 & 1,28 & 4,37 & $0,000^{* *}$ \\
\hline & Advantages for groceries & 2,23 & 1,12 & 2,35 & 1,23 & 0,90 & 0,367 \\
\hline & Advantages for tickets & 3,32 & 1,33 & 3,79 & 1,04 & 3,61 & $0,000^{* *}$ \\
\hline & Advantages for Banking & 3,30 & 1,37 & 4,13 & 1,13 & 5,97 & $0,000^{* *}$ \\
\hline & Credit Card risk is same & 2,91 & 1,44 & 2,54 & 1,35 & 2,37 & $0,018^{* *}$ \\
\hline & $\begin{array}{l}\text { Online shopping is more } \\
\text { convenient }\end{array}$ & 3,75 & 1,35 & 3,81 & 1,08 & 0,43 & 0,671 \\
\hline & Problems can be solved & 3,23 & 1,34 & 2,89 & 1,07 & 2,51 & $0,013^{* *}$ \\
\hline & Better than Catalog Shopping & 2,96 & 1,26 & 3,61 & 1,04 & 5,03 & $0,000^{* *}$ \\
\hline & $\begin{array}{l}\text { Online Shopping is more } \\
\text { preferable }\end{array}$ & 2,44 & 1,36 & 3,17 & 1,21 & 5,13 & $0,000^{* *}$ \\
\hline & I would like to shop online & 3,04 & 1,34 & 4,05 & 0,99 & 7,82 & $0,000^{* *}$ \\
\hline
\end{tabular}

${ }^{* *}$ significant at $5 \%$ level of significance 
Comparison of E-Commerce Users with Non E-commerce Users:

As shown in Table 7, attitudes of ecommerce users toward internet shopping are higher than attitudes of non ecommerce users in both Turkey and Romania. When we compare Turkey with Romania attitudes of e-commerce, users in Turkey are more positive (3.56) than attitudes of ecommerce users in Romania (3.32). When we compare the attitudes of non e-commerce users in both countries, attitudes of non e-commerce users in Turkey is higher (3.14) than the attitudes of non e-commerce users in Romania (2.57). There is a statistically significant difference between both groups in terms of attitudes.

Table 7: Comparison of e-commerce Users with Non Users

\begin{tabular}{|c|c|c|c|c|c|c|}
\hline & & $\mathbf{N}$ & $\begin{array}{c}\text { Mea } \\
\text { n }\end{array}$ & $\begin{array}{c}\text { Std. } \\
\text { Deviation }\end{array}$ & $\mathrm{t}$ & $\mathbf{p}$ \\
\hline \multirow[b]{2}{*}{ Romania } & E-commerce users & 92 & 3,32 & 0,69 & \multirow{2}{*}{$\begin{array}{r}5,9 \\
9\end{array}$} & \multirow[b]{2}{*}{$0,000^{* *}$} \\
\hline & $\begin{array}{l}\text { Non e-commerce } \\
\text { users }\end{array}$ & 50 & 2,57 & 0,75 & & \\
\hline \multirow{2}{*}{ Turkey } & E-commerce users & $\begin{array}{r}13 \\
8\end{array}$ & 3,56 & 0,63 & \multirow{2}{*}{$\begin{array}{r}2,1 \\
2\end{array}$} & \multirow{2}{*}{$0,036^{* *}$} \\
\hline & $\begin{array}{l}\text { Non e-commerce } \\
\text { users }\end{array}$ & 47 & 3,14 & 0,53 & & \\
\hline \multirow{2}{*}{ Both Country } & E-commerce users & $\begin{array}{r}23 \\
0\end{array}$ & 3,34 & 3,34 & \multirow{2}{*}{$\begin{array}{r}6,1 \\
0\end{array}$} & \multirow{2}{*}{$0,000^{* *}$} \\
\hline & $\begin{array}{l}\text { Non e-commerce } \\
\text { users }\end{array}$ & 97 & 2,84 & 2,84 & & \\
\hline
\end{tabular}

${ }^{* *}$ significant at $5 \%$ level of significance

\section{Comparison of Male and Female Attitudes toward E-Shopping}

When we looked at the attitudes of male and female, attitudes of male towards online shopping is more positive (3.31) than attitudes of females $(3,12)$ toward online shopping in both countries together.

Table 8: Comparison of Male and Female

\begin{tabular}{|c|c|c|c|c|c|c|}
\hline & & $\mathbf{N}$ & Mean & $\begin{array}{c}\text { Std. } \\
\text { Deviation }\end{array}$ & $\mathbf{t}$ & $\mathbf{p}$ \\
\hline \multirow{2}{*}{ Romania } & Female & 119 & 3,03 & 0,72 & \multirow{2}{*}{0,99} & \multirow{2}{*}{0,325} \\
\hline & Male & 23 & 3,21 & 0,82 & & \\
\hline \multirow[b]{2}{*}{ Turkey } & Female & 79 & 326 & 060 & \multirow[b]{2}{*}{0,77} & \multirow[b]{2}{*}{0,445} \\
\hline & Male & 106 & 3,33 & 0,63 & & \\
\hline \multirow{2}{*}{ Both Country } & Female & 198 & 3,12 & 0,74 & \multirow{2}{*}{2,38} & \multirow{2}{*}{$0,018^{* *}$} \\
\hline & Male & 129 & 3,31 & 0,64 & & \\
\hline
\end{tabular}

**significant at $5 \%$ level of significance 


\section{Comparison of Experiences and Non Experienced Internet Users}

When we compared the attitudes of consumers based on their internet experience, attitudes of more experienced internet users have more positive attitudes toward online shopping than less experienced internet users in both Turkey and Romania. The more consumers are getting to gain internet experience, the more they will be willing to use online shopping relative to less experienced consumers.

Table 9: Comparison of Experienced and Less Experienced Internet Users

\begin{tabular}{|c|c|c|c|c|c|c|}
\hline & $\begin{array}{c}\text { How long have you been } \\
\text { using internet? }\end{array}$ & $\mathbf{N}$ & Mean & $\begin{array}{c}\text { Std. } \\
\text { Deviation }\end{array}$ & $\mathbf{t}$ & $\mathbf{p}$ \\
\hline \multirow{2}{*}{ Romania } & 5 years and more & 93 & 3,19 & 0,76 & \multirow{2}{*}{2,84} & \multirow{2}{*}{$0,070^{*}$} \\
\hline & Under 5 years & 49 & 2,80 & 0,82 & & \\
\hline \multirow{2}{*}{ Turkey } & 5 years and more & 51 & 3,45 & 0,74 & \multirow{2}{*}{2,09} & \multirow{2}{*}{$\begin{array}{l}0,038^{*} \\
*\end{array}$} \\
\hline & Under 5 years & 134 & 3,24 & 0,55 & & \\
\hline \multirow{2}{*}{ Both country } & 5 years and more & 144 & 3,28 & 0,76 & \multirow{2}{*}{1,99} & \multirow{2}{*}{$\begin{array}{l}0,046^{*} \\
*\end{array}$} \\
\hline & Under 5 years & 183 & 3,13 & 0,66 & & \\
\hline
\end{tabular}

** significant at $5 \%$ level of significance

*significant at the $10 \%$ level of significance

\section{Correlation Analysis}

Table 10 shows the results of correlation analysis between the important factors of consumers who shop online and their attitudes toward online shopping. There is a statistically significant and positive relationship between prices of products, convenience, time constraints, home delivery and more information with attitudes of consumers toward online shopping in both Turkey and Romania. But there is not a statistically significant relationship between product quality and trust to e-commerce site with attitudes of consumers towards shopping online in Turkey. As shown in following table, trust is the biggest hesitation of consumers in online shopping. The findings of this study are aligned with previous research results in the literature (Vijayasarathy 2004:747762, Jarvenpaa, Tractinsky and Vitale 2000: 45-71, McCloskey and Whiteley 2002: 185195).

Table 10: Correlation Analysis between Factors and Attitudes

\begin{tabular}{|l|r|r|r|c|}
\hline \multirow{2}{*}{} & \multicolumn{2}{|c|}{ Romania (n=142) } & \multicolumn{2}{c|}{ Turkey (n=185) } \\
\cline { 2 - 5 } & Correlation & \multicolumn{1}{|c|}{ Sig. } & Correlation & \multicolumn{1}{c|}{ Sig. } \\
\hline Prices of Products & 0,453 & 0,000 & 0,127 & $0,085^{*}$ \\
\hline Convenience & 0,509 & 0,000 & 0,296 & $0,000^{* *}$ \\
\hline Product Quality & 0,488 & 0,000 & 0,109 & 0,139 \\
\hline Time Constraints & 0,428 & 0,000 & 0,214 & $0,003^{* *}$ \\
\hline Home Delivery & 0,474 & 0,000 & 0,136 & $0,064^{*}$ \\
\hline More Information & 0,395 & 0,000 & 0,217 & $0,003^{* *}$ \\
\hline Trust to e-commerce site & 0,432 & 0,000 & 0,109 & 0,138 \\
\hline Monthly payments to Credit Cards & 0,403 & 0,000 & 0,263 & $0,000^{* *}$ \\
\hline Service Quality & 0,499 & 0,000 & 0,196 & $0,007^{* *}$ \\
\hline Internet Security & 0,341 & 0,000 & 0,156 & $0,033^{* *}$ \\
\hline Weather Conditions & 0,190 & 0,024 & 0,219 & $0,003^{* *}$ \\
\hline
\end{tabular}

** significant at $5 \%$ level of significance

*significant at the $10 \%$ level of significance 


\section{Conclusion}

The results of the study explain and identify some characteristics of consumers' attitudes toward online shopping both in Turkey and Romania. First, the most three important reasons for consumers not to shop online are online security, would like to buy things by touching and feeling, and prefer traditional shopping. Especially Turkish people regard shopping as an organic and social experience, enjoying going around and spending time in bazaars and shopping centers, searching for bargains, and having an outgoing activity with the family while shopping. Second, it is seen that the most advantageous items to purchase online are books, tickets and CDs. Groceries and clothing are the most unsuitable items for online purchases. Because especially inspection of these items before purchase are important, and returning these items is also a major issue for these products. Third, it is found that the most important factors affecting online buying decisions are convenience, better prices and detailed product information. Econsumer users purchased products online because online stores provided them with convenience, better prices and more information about the products and services they provided. And finally, it is determined that both e-commerce users and non users have a positive attitude toward online shopping. Both groups would like to shop or continue to shop online. One of the limitations of this research is that the data gathered from graduate students of universities in both Turkey and Romania.

There are significant differences between the attitudes of different groups. Attitudes of e-commerce users, graduate students, more experienced internet users and consumers who have internet access at their homes are more positive than attitudes of non e-commerce users, less experienced internet users, consumers who don't have internet access in their homes respectively both in Turkey and Romania. There is also a positive relationship between prices of products, convenience, time constraints, home delivery and more information and attitudes of consumers toward online shopping. Consumers who rate these factors high, their attitudes toward online shopping are also high.

There are some direct implications of these findings for the managers and entrepreneurs of online stores. They have to be able to provide goods and services that are more suitable for internet or online shopping. They have to take necessary actions to make sure that their online site is secure, trusted and reliable. They also should have good quality website, high service and product quality, provide convenience, better prices and time savings for their customers to positively influence their attitudes and behavior so that it leads potential consumers to shop online and retain the existing customers. These are all very important information for managers and strategists of online stores when they try to determine and implement right strategies for their business and try to focus on their core competences to be able to compete. On the further research, data can be collected from consumers to generalize the results for the entire population of Turkey and Romania. Secondly, data should also be collected from customers of specific online stores to be able to measure the quality of goods and services of these online stores.

\section{References}

Barutçu, S. (2007). "The Role of Internet Based Supply Chain Management on ETailing Industry and E-Customer Satisfaction Level from Cargo Carriers," Proceedings of 5th International Logistics and Supply Chain Management Congress, Okan University, İstanbul, Turkey, 232-241.

Bosnjak, M., Galesic, M. \& Tuten T. (2007). "Personality Determinants of Online Shopping: Explaining Online Purchase Intentions Using a Hierarchical Approach," Journal of Business Research, 60, 597-605

Case, T., Burns, O. M. \& Dick, G. N. (2001). "Drivers of Online Purchases among U.S.Students," Proceedings of the 7th American conference on Information Systems, p. 900-907. 
Jarvenpaa, S. L., Tractinsky, N., \& Vitale, M. (2000). Consumer Trust in an Internet Store, Information Technology and Management, 1, 45-71.

Li, N. \& Zhang P. (2002). "Consumer Online Shopping Attitudes and Behavior: An Assessment of Research," Proceedings of Eight American Conference on Information Systems, p. 508-517.

Lian, J. W. \& Lin, T. M (2008). "Effects of Consumer Characteristics on their Acceptance of Online Shopping: Comparisons among Different Product Types," Computers in Human Behavior, 24, 48-65.

Liao, Z. \& Cheung, M. T. (2001). "Internetbased E-shopping and Consumer Attitudes: An Empirical Study," Information and Management, 38, 299-306.

McCloskey, D. W. \& Whiteley, D. (2002). Electronic Commerce Acceptance: A Study Comparing the United States and the United Kingdom, Strategies for ecommerce success, Hersey, PA, USA, Idea Publishing, p. 185-195.

Noce, A. A. \& McKeown L. (2008). “A New Benchmark for Internet Use: A Logistic Modeling of Factors Influencing Internet Use in Canada, 2005," Government Information Quarterly, 25, 462-476.

Sandal, E. K., Karabulut, M. \& Gürbüz, M. (2005). "The Place of Turkey Based on Socio-Economic Criteria and EU," Firat University Journal of Social Science, 15 (1), 1-14.

Shergill, G. S. \& Chen, Z. (2005). "Webbased Shopping: Consumers' Attitudes towards Online Shopping in New Zealand,"
Journal of Electronic Commerce Research, 6 (2), 79-94.

Shih, H. P., (2004). "An Empirical Study on Predicting User Acceptance of E-Shopping on the Web," Information \& Management, 41, 351-368.

Soopramanien, D. G. R. \& Robertson, A. (2007). "Adoption and Usage of Online Shopping: An Empirical Analysis of the Characteristics of "Buyers" "Browsers" and "Non-Internet Shoppers," Journal of Retailing and Consumer Services, 14, 73-82.

Sorce, P. Perotti, V. and Widrick, S. (2005). "Attitude and Age Differences in Online Buying," International Journal of Retail and Distribution Management, 33 (2), 122-132.

Turanl, M., Özden, Ü.H. \& Türedi, S. (2006). "Analysis of the Economical Similarities of European Union Members and Candidate Countries with Cluster Analysis," İstanbul University Journal of Social Science, 5 (9), 95-108.

Vijayasarathy. L. R. (2004). "Predicting Consumer Intentions to Use On-Line Shopping: The Case for an Augmented Technology Acceptance Model," Information \& Management,41, 747-762 http://www.aneki.com/comparison.php?c ountry_1=Turkey\&country_2=Romania(20 February 2011) www.sellerator.ro/stiri.html,13 November 2008

www.mfinante.ro www.gpec.ro/noutati-si-opinii/noutati$\mathrm{pec} / \mathrm{s}$-au-desemnat-castigatorii-galeipremiilor-ecommerce-2009.html www.sellerator.ro/stiri.html,13 November 2008

http://www.underclick.ro/articol-2613umparaturile_online_in_romania.html, 12 November 2010 